Crop Breeding and Applied Biotechnology 16: 48-54, 2016

Brazilian Society of Plant Breeding. Printed in Brazil

\title{
ARTICLE
}

http://dx.doi.org/10.1590/1984-70332016v16n1a8

\section{In vitro callus induction and micropropagation of Thymus persicus (Lamiaceae), an endangered medicinal plant}

\author{
Ziba Bakhtiar ${ }^{1}$, Mohammad Hossein Mirjalili ${ }^{1 *}$ and Ali Sonboli ${ }^{2}$
}

Received 07 April 2015

Accepted 25 August 2015

\begin{abstract}
This is the first attempt towards an efficient regeneration protocol for an endangered and valuable medicinal plant, Thymus persicus using in vitro callus induction and indirect organogenesis. Callus induction was performed on MS medium supplemented with different concentrations of NAA and 2,4-D, alone or in combination with BAP and KN. Maximum callus induction (100\%) was achieved from internode explants cultured on MS medium fortified with $2.0 \mathrm{mg} \mathrm{L^{-1 }} N A A$ and $0.5 \mathrm{mg} \mathrm{L}^{-1} \mathrm{KN}$. The highest frequency of shoot multiplication (96\%) was observed with $2.0 \mathrm{mg} \mathrm{L}^{-1} B A P+1.0 \mathrm{mg} \mathrm{L^{-1 }} N A A$. The maximum number of rootlets $(16.6 \pm 1.4)$ was induced on half-strength MS medium with 0.5 and $1.0 \mathrm{mg} \mathrm{L} L^{-1} I B A$. Rooted plantlets were then successfully grown and acclimatized in the greenhouse with a 70-85\% survival rate. The benefits of the protocol described here include all-year-round application, germplasm conservation, suitability for commercial production and also for the biotechnological production of pentacyclic triterpenoids.
\end{abstract}

Key words: Callus culture, regeneration, organogenesis, pentacyclic triterpenoids.

\section{INTRODUCTION}

The genus Thymus L. (Lamiaceae) comprises three hundred species of herbaceous annuals and perennials widely distributed throughout the Old World (Morales 2002). Thymus species serve as a natural source of monoterpene-phenolic oils, oleoresins, and fresh and dried herbs (Lawrence and Tucker 2002), and have been used for many centuries in traditional medicine (Stahl-Biskup 2002) due to their antiseptic, carminative, antimicrobial, antiviral and antioxidative properties (Reddy et al. 2014). This genus is represented in the flora of Iran by fourteen species, four of which, including Thymus persicus (Ronniger ex Rech. f.) Jalas, are endemic (Jalas 1982). T. persicus as a cross-pollination plant is restricted to some regions of northwest Iran (Mozaffarian 1996). The plant's aerial part is interesting as a source of pentacyclic triterpenoids (PTs) i.e. betulinic acid (BA), oleanolic acid (OA) and ursolic acid (UA) derived from a squalene precursor (Bakhtiar et al. 2014). BA, $\mathrm{OA}$ and UA are highly valuable compounds because of their wide spectrum of biological activities, such as anti-inflammatory, hepatoprotective, antitumor, anti-HIV, antimicrobial, antifungal, anti-ulcer, gastroprotective, hypoglycemic, and antihyperlipidemic (Liu et al. 2012, Chudzik et al. 2015).

Owing to a narrow range of distribution, a low propagation rate in nature, land-use disturbances, mine over-exploitation, and over-collection of wild plants for medicinal purposes (Figure 1), T. persicus is now almost extinct and is listed as an extremely vulnerable species in Iran (Jalili and Jamzad 1999). There is an obvious need to develop an efficient regeneration system for effective conservation and rapid multiplication in order to replenish highly impoverished populations.

In vitro propagation (IVP) of endangered plants can offer considerable benefits, including rapid cultivation of species that have limited reproductive capacity and exist in threatened habitats (Fay 1992). IVP methods are also essential components of plant genetic resource management and are becoming increasingly important for the conservation of rare and endangered plant species (Almeida et al. 2005, Sidhu 2010). These techniques also facilitate the application of genetic manipulation procedures (Ueno et al. 1996) and long-term storage (Hawkes et al. 2000). In addition, indirect IVP through

\footnotetext{
${ }^{1}$ Shahid Beheshti University, Medicinal Plants and Drugs Research Institute, Department of Agriculture, G. C., Evin, Tehran, Iran. *E-mail: m-mirjalili@sbu.ac.ir

${ }^{2}$ Shahid Beheshti University, Medicinal Plants and Drugs Research Institute, Department of Biology
} 

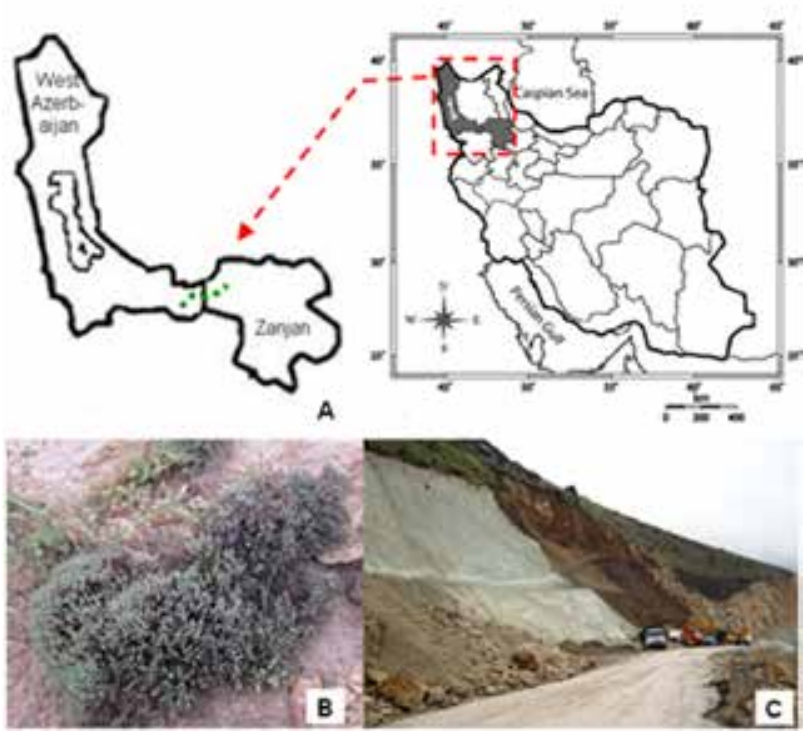

Figure 1. Thymus persicus: A. Distribution map; B. Wild population; C. Mine exploitation in the habitat of the plant.

callus culture is considered to be the most efficient method for crop improvement by the production of somaclonal and gametoclonal variants. This technology has vast potential to produce superior quality plants and allows the isolation of useful variants from well-adapted high-yielding genotypes with better disease resistance and stress tolerance (Brown and Thorpe 1995). Certain types of callus cultures give rise to clones that have inheritable characteristics different from those of parent plants due to the occurrence of somaclonal variability (George 1993), which can lead to the development of commercially important improved varieties (Lee and Chen 2014). IVP protocols have already been established for Thymus species, such as T. vulgaris and T. longicaulis (Ozudogru et al. 2011), and T. lotocephalus (Coelho et al. 2012). Recently, micropropagation of $T$. persicus via direct organogenesis has been reported from our laboratory (Bakhtiar et al. 2014). The present work reports an efficient protocol for achieving high-frequency shoot induction and plant regeneration, starting from a callus culture of $T$. persicus, and for the reintroduction of the produced plants into their natural habitat.

\section{MATERIAL AND METHODS}

\section{Plant material and sterilization procedure}

Mother plants of $T$. persicus were collected from wild populations in the village of Baderloo (lat $36^{0} 28^{\prime} \mathrm{N}$, long $47^{\circ} 13^{\prime} \mathrm{E}$, and alt 2,500 $\mathrm{m}$ asl), Takab, in northwest Iran (Figure 2 A). Based on Bakhtiar et al. (2014), healthy

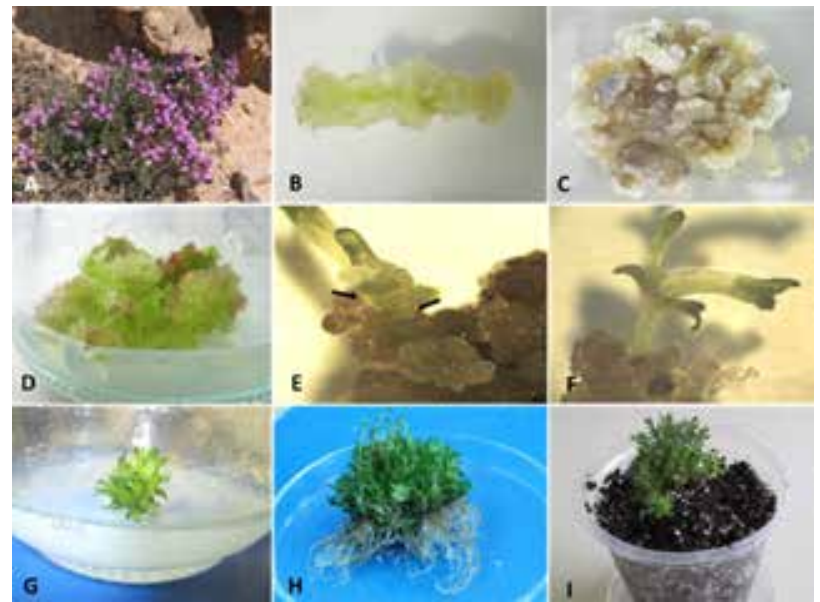

Figure 2. In vitro propagation of Thymus persicus: A. Wild plant; B. Internode explant after 21 days on a medium supplemented with $2.0 \mathrm{mg}$ $\mathrm{L}^{-1} \mathrm{NAA}+0.5 \mathrm{mg} \mathrm{L}^{-1} \mathrm{KN}$; C. Callus induction after 30 days in the dark; D. 3-Days-old callus in light; E, F. Shoot formation from callus after incubation for 3 weeks on a medium supplemented with $2.0 \mathrm{mg} \mathrm{L}^{-1} \mathrm{BAP}+$ $0.5 \mathrm{mg} \mathrm{L}^{-1} \mathrm{NAA}$; G. Number of shoots after incubation for 4 weeks on medium supplemented with $2.0 \mathrm{mg} \mathrm{L}^{-1} \mathrm{BAP}+1.0 \mathrm{mg} \mathrm{L}^{-1} \mathrm{NAA} ; \mathbf{H}$. Root formation with $1.0 \mathrm{mg} \mathrm{L}^{-1} \mathrm{BA}$; I. Transplanted plant in pots.

plants were separated from the mother plant and washed with running water for $30 \mathrm{~min}$ 2-3 times before receiving a pre-treatment with liquid detergent for 30-40 min. Washed explants were immersed in $70 \%$ ethanol for $1 \mathrm{~min}$, followed by washing with sterile distilled water, and then soaked in $0.1 \%$ sodium hypochlorite $(\mathrm{NaOCl})$ containing a few drops of Tween 20, before being rinsed for $10 \mathrm{~min}$ with sterile double distilled water.

\section{Culture conditions and callus induction}

Leaf and intermode explants were excised from 1 -year-old in vitro T. persicus plantlets (Bakhtiar et al. 2014), and were then sectioned into 1-2 cm-long segments. Callus cultures were induced on MS medium (Murashige and Skoog 1962) supplemented with 3\% sucrose, $0.8 \%$ agar (Merck, Darmstadt, Germany) and different concentrations of auxins 1-naphthalene-acetic acid (NAA) and 2,4-dichlorophenoxyacetic acid (2,4-D), alone or in combination with cytokinins 6-benzylaminopurine (BAP) and kinetin (KN) (Table 1). Callus induction took place in $250 \mathrm{~mL}$ glass jars, containing $40 \mathrm{ml}$ of medium, sealed with plastic caps. Cultures were incubated in the dark for 7 days and then incubated under a 16 -h photoperiod provided for 30 days by cool-white fluorescent lamps (Philips, $58 \mathrm{~W}$, Holland) at a photon flux density of $40 \mu \mathrm{mol} \mathrm{m} \mathrm{m}^{-2} \mathrm{~s}^{-1}$ at 25 $\pm 2{ }^{\circ} \mathrm{C}$. Each glass jar was considered as an experimental unit and the experiment was conducted at least thrice with 10 replicates per treatment. The cultures were subcultured 
Table 1. Effect of auxin and cytokinin type and concentration on callus induction from leaf and internode explants of Thymus persicus

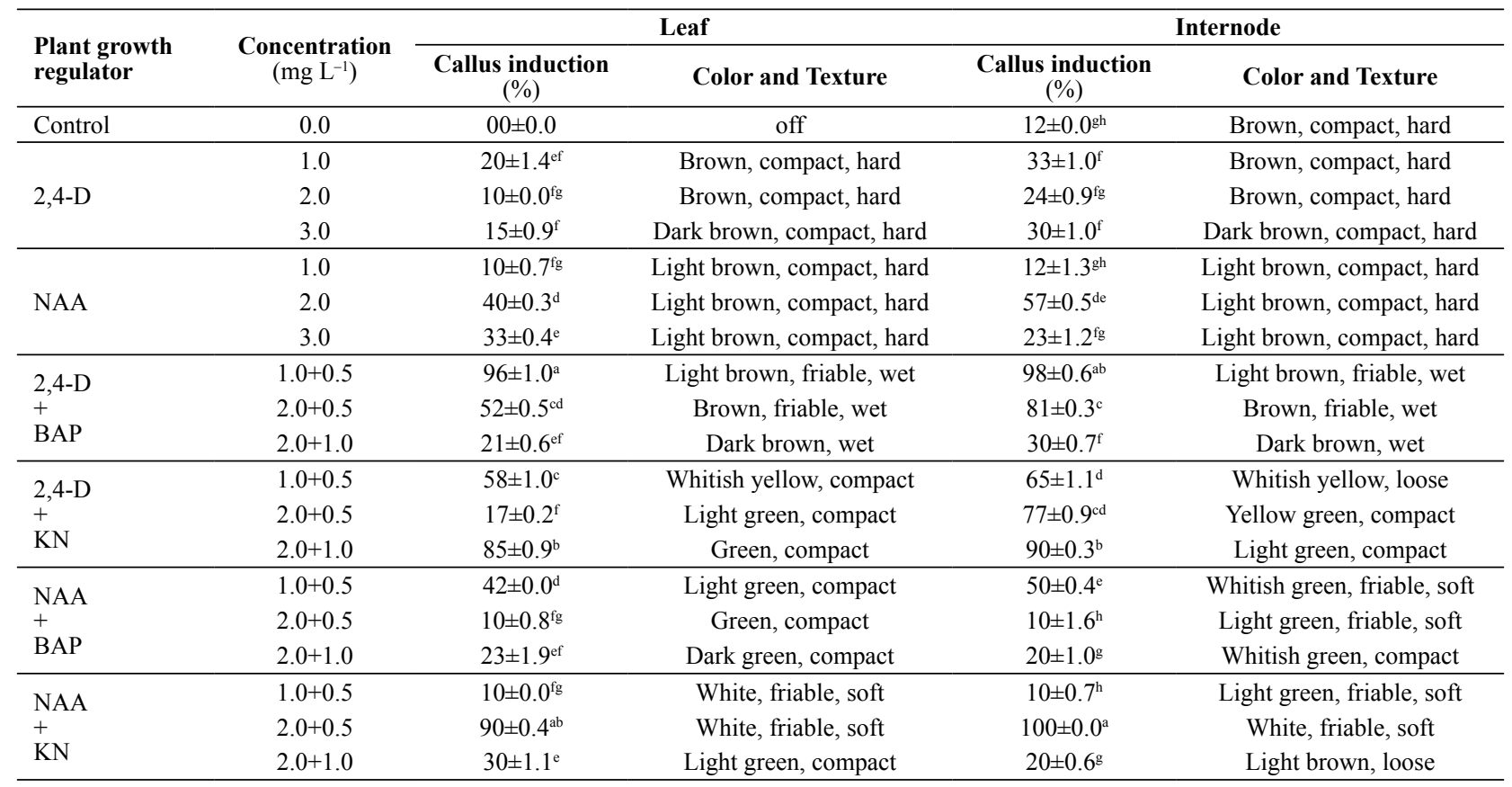

Each value represents Mean \pm SE. Mean values followed by the same letter are not significantly different at $\mathrm{P}<0.05$ (Least Significant Difference Test). Results recorded after 3 weeks of culture.

at regular intervals of 21 days on fresh MS medium. The induction rate (\%) and nature of calli (color and texture) were recorded day 35 of induction.

\section{Shoot multiplication and root induction}

1-month-old white, friable and soft calli were subcultured on MS media containing different concentrations of BAP, KN, NAA and indole-3-butyric acid (IBA) (Table 2) to induce multiple shoots. The shoot multiplication took place in $250 \mathrm{ml}$ glass jars, containing $50 \mathrm{ml}$ of medium, sealed with plastic caps. The effects of different plant growth regulators (PGRs) on multiple shoot induction and shoot elongation were periodically recorded after 4 weeks. Each glass jar was considered as an experimental unit and the experiment was conducted at least thrice with 5 replicates per treatment. The number of shoots per callus and the rate of shoot induction (\%) were counted at day 35 of regeneration (Table 2). Regenerated shoots $(1-1.5 \mathrm{~cm})$ were then transferred to MS medium containing $2.0 \mathrm{mg} \mathrm{L}^{-1} \mathrm{BAP}+1.0 \mathrm{mg} \mathrm{L}^{-1} \mathrm{NAA}$ to elongate shoots for 30 days. The healthy elongated shoots (2-2.5 $\mathrm{cm})$ were then transferred to half-strength MS basal medium supplemented with different concentrations of IBA and NAA (Table 3) to root for four weeks, and then the rooting rate was counted.

\section{Acclimatization}

Plantlets with well-developed roots (average root length exceeding $10 \mathrm{~mm}$ ) were removed from the culture medium and washed gently with distilled water to remove the adhering medium. Acclimatization of plantlets was carried out according to the method recently described by Bakhtiar et al. (2014).

\section{Statistics}

All experiments were conducted under controlled conditions with three replications. The statistical analysis was performed using one-way analysis of variance (ANOVA) and the mean values of different treatments were compared by the least significant difference (LSD) test at $\mathrm{P} \leq 0.05$.

\section{RESULTS AND DISCUSSION}

Callus induction was observed on MS medium supplemented with different concentrations of 2,4-D and NAA, alone or in combination with BAP and KN (Table 1). Callus initiation was achieved from the explants within 2530 days of inoculation (Figure 2B). Both types of selected explants gave the maximum percentage of callusing, which confirms previous studies on various plants including Mentha spicata (Poovaiah et al. 2006), Thymus hyemalis (Nordine et al. 2014), Lavandula angustifolia (Machado et al. 2014), 
and Artemisia pallens (Nathar and Yatoo 2014). All types of media produced callus on both explants except PGRs-free medium (control), which did not produce callus on leaf explants. Depending on the concentration and combination of PGRs, the frequency of callus formation and nature of calli (color and texture) varied widely. Initially, leaf folding and nodal bulging was observed. The callus color and texture ranged from white to dark, and soft to compact-hard (Table 1). At concentrations 1.0 and $2.0 \mathrm{mg} \mathrm{L}^{-1} 2,4-\mathrm{D}$, both leaf and internodal explants produced brown calli, whereas at a higher concentration $\left(3.0 \mathrm{mg} \mathrm{L}^{-1}\right)$, compact dark brown calli were formed. In MS media supplemented with NAA, explants developed light brown calli. Our results showed that the use of 1.0 and $2.0 \mathrm{mg} \mathrm{L}^{-1} \mathrm{NAA}$ in combination with $0.5 \mathrm{mg} \mathrm{L}^{-1} \mathrm{BAP}$ in induction medium induces white friable calli in internodal explants, whereas NAA in combination with $0.5 \mathrm{mg} \mathrm{L}^{-1} \mathrm{KN}$ induces white friable calli in both leaf and internodal explants. Alternatively, $1.0 \mathrm{mg} \mathrm{L}^{-1} 2,4-\mathrm{D}$ combined with $0.5 \mathrm{mg} \mathrm{L}^{-1} \mathrm{BAP}$ also induced friable calli that were generally light brown (Table 1). Maximum callus induction $(100 \%)$ was achieved from internode explants cultured on MS medium fortified with $2.0 \mathrm{mg} \mathrm{L}^{-1} \mathrm{NAA}$ and $0.5 \mathrm{mg} \mathrm{L}^{-1} \mathrm{KN}$ (Figure 2C) followed by $1.0 \mathrm{mg} \mathrm{L}^{-1} 2,4-\mathrm{D}$ and $0.5 \mathrm{mg} \mathrm{L}^{-1} \mathrm{BAP}(98 \%)$.

The calli generated from different callus induction media were transferred to regeneration media containing different concentrations of BAP and $\mathrm{KN}$, alone or in combination with NAA and IBA (Figure 2D-2F). The percentage of regeneration and number of shoots varied. The response of calli to the different concentrations of PGRs used for shoot formation is represented in Table 2. Various concentrations of BAP in combination with NAA significantly influenced the formation of shoots. The highest rate of regeneration was obtained from calli cultured on MS medium supplemented with $2.0 \mathrm{mg} \mathrm{L}^{-1}$ $\mathrm{BAP}$ and $1.0 \mathrm{mg} \mathrm{L}^{-1} \mathrm{NAA}$, which was therefore selected as the optimal shoot multiplication medium for further experiments. This enabled a $96 \%$ shoot proliferation and produced an average of $6.8 \pm 1.0$ healthy shoots longer than $0.5 \mathrm{~cm}$ per regenerating callus (Table 2, Figure $2 \mathrm{G}$ ). Halving the BAP and NAA content produced only a

Table 2. Effect of auxin and cytokinin type and concentration on shoot induction from callus culture of Thymus persicus

\begin{tabular}{|c|c|c|c|c|}
\hline Plant growth regulator & $\begin{array}{c}\text { Concentration } \\
\left(\mathrm{mg} \mathrm{L}^{-1}\right)\end{array}$ & Regeneration (\%) & $\begin{array}{c}\text { Mean number of shoots } \\
\text { (no. } \pm \text { SE) }\end{array}$ & $\begin{array}{c}\text { Mean shoot length } \\
(\mathrm{cm} \pm \mathrm{SE})\end{array}$ \\
\hline Control & 0.0 & $78^{\mathrm{c}}$ & $1.80 \pm 0.3^{\mathrm{b}}$ & $0.49 \pm 0.05^{\mathrm{ab}}$ \\
\hline \multirow{4}{*}{ BAP } & 0.5 & $56^{\mathrm{f}}$ & $0.80 \pm 0.5^{b}$ & $0.30 \pm 0.03^{b}$ \\
\hline & 1.0 & $60^{\mathrm{e}}$ & $1.50 \pm 0.2^{\mathrm{b}}$ & $0.40 \pm 0.07^{\mathrm{ab}}$ \\
\hline & 2.0 & $80^{\mathrm{bc}}$ & $1.70 \pm 0.4^{\mathrm{b}}$ & $0.22 \pm 0.04^{b}$ \\
\hline & 3.0 & $64^{\mathrm{d}}$ & $0.80 \pm 0.3^{\mathrm{b}}$ & $0.29 \pm 0.01^{\mathrm{b}}$ \\
\hline \multirow{4}{*}{$\mathrm{KN}$} & 0.5 & $75^{\mathrm{cd}}$ & $1.5 \pm 0.6^{\mathrm{b}}$ & $0.20 \pm 0.11^{\mathrm{b}}$ \\
\hline & 1.0 & $78^{\mathrm{c}}$ & $1.0 \pm 0.1^{\mathrm{b}}$ & $0.43 \pm 0.01^{\mathrm{ab}}$ \\
\hline & 2.0 & $80^{\mathrm{bc}}$ & $0.9 \pm 0.7^{b}$ & $0.50 \pm 0.12^{\mathrm{a}}$ \\
\hline & 3.0 & $75^{\mathrm{cd}}$ & $1.1 \pm 0.9^{\mathrm{b}}$ & $0.32 \pm 0.04^{b}$ \\
\hline \multirow{4}{*}{$\begin{array}{l}\text { BAP } \\
+ \\
\text { NAA }\end{array}$} & $1.0+0.5$ & $94^{\mathrm{ab}}$ & $2.3 \pm 0.3^{\mathrm{ab}}$ & $0.87 \pm 0.01^{\mathrm{a}}$ \\
\hline & $2.0+0.5$ & $78^{\mathrm{c}}$ & $3.4 \pm 0.5^{\mathrm{ab}}$ & $0.70 \pm 0.01^{\mathrm{a}}$ \\
\hline & $2.0+1.0$ & $96^{\mathrm{a}}$ & $6.8 \pm 1.0^{\mathrm{a}}$ & $0.57 \pm 0.01^{\mathrm{a}}$ \\
\hline & $3.0+1.0$ & $88^{\mathrm{b}}$ & $3.9 \pm 0.2^{\mathrm{ab}}$ & $0.30 \pm 0.07^{\mathrm{ab}}$ \\
\hline \multirow{4}{*}{$\begin{array}{l}\mathrm{KN} \\
+ \\
\text { NAA }\end{array}$} & $1.0+0.5$ & $92^{\mathrm{ab}}$ & $1.9 \pm 0.5^{\mathrm{ab}}$ & $0.64 \pm 0.07^{\mathrm{a}}$ \\
\hline & $2.0+0.5$ & $80^{\mathrm{bc}}$ & $1.7 \pm 0.7^{\mathrm{b}}$ & $0.54 \pm 0.01^{\mathrm{a}}$ \\
\hline & $2.0+1.0$ & $64^{\mathrm{d}}$ & $2.0 \pm 0.4^{\mathrm{ab}}$ & $0.40 \pm 0.03^{\mathrm{ab}}$ \\
\hline & $3.0+1.0$ & $50^{\mathrm{fg}}$ & $2.7 \pm 0.1^{\mathrm{ab}}$ & $0.35 \pm 0.03^{\mathrm{ab}}$ \\
\hline \multirow{4}{*}{$\begin{array}{l}\text { BAP } \\
+ \\
\text { IBA }\end{array}$} & $1.0+0.5$ & $40^{\mathrm{g}}$ & $2.8 \pm 0.7^{\mathrm{ab}}$ & $0.39 \pm 0.11^{\mathrm{ab}}$ \\
\hline & $2.0+0.5$ & $77^{\mathrm{c}}$ & $1.3 \pm 0.3^{\mathrm{b}}$ & $0.40 \pm 0.04^{\mathrm{ab}}$ \\
\hline & $2.0+1.0$ & $80^{\mathrm{bc}}$ & $5.8 \pm 0.6^{\mathrm{a}}$ & $0.47 \pm 0.06^{\mathrm{ab}}$ \\
\hline & $3.0+1.0$ & $57^{\mathrm{ef}}$ & $2.2 \pm 0.5^{\mathrm{ab}}$ & $0.37 \pm 0.03^{\mathrm{ab}}$ \\
\hline \multirow{4}{*}{$\begin{array}{l}\text { KN } \\
+ \\
\text { IBA }\end{array}$} & $1.0+0.5$ & $30^{\mathrm{h}}$ & $2.1 \pm 0.3^{\mathrm{ab}}$ & $0.25 \pm 0.01^{b}$ \\
\hline & $2.0+0.5$ & $80^{\text {bc }}$ & $2.1 \pm 0.9^{\mathrm{ab}}$ & $0.30 \pm 0.10^{\mathrm{b}}$ \\
\hline & $2.0+1.0$ & $78^{c}$ & $1.3 \pm 0.1^{\mathrm{b}}$ & $0.31 \pm 0.08^{b}$ \\
\hline & $3.0+1.0$ & $56^{\mathrm{f}}$ & $2.0 \pm 0.3^{\mathrm{ab}}$ & $0.22 \pm 0.03^{b}$ \\
\hline
\end{tabular}

Each value represents Mean \pm SE. Mean values followed by the same letter are not significantly different at $\mathrm{P}<0.05$ (Least Significant Difference Test). Results recorded after 3 weeks of culture. 
slight decrease in shoot proliferation percentage (94\%). Supplementing the proliferation medium with $\mathrm{KN}$ resulted in a less satisfactory shoot proliferation than with BAP. The highest regeneration rates were only $92 \%$ when the medium contained $1.0 \mathrm{mg} \mathrm{L}^{-1} \mathrm{KN}$ and $0.5 \mathrm{mg} \mathrm{L}^{-1} \mathrm{NAA}$. Different concentrations of $\mathrm{KN}$ reduced shoot number and length, and shoot formation varied between 30-96\%. Shoot formation from calli has been previously achieved by cytokinin or auxin supplementation or by varying the mineral concentration in the medium (Kour et al. 2014). The immense activity of BAP compared to other cytokinins is reported in many plants, including Salvia officinalis (Tawfik and Mohamed 2007), Thymus bleicherianus (Aicha and Abdelmalek 2014), and Mandevilla guanabarica (Zorat Cordeiro et al. 2014). As shown in Table 2, calli cultured on PGR-free MS medium exhibited a high shoot formation rate $(78 \%)$. It can be concluded that the calli were habituated to the PGRs used for callus induction, especially BAP. These results are in agreement with those obtained by Bennici and Bruschi (1999) for Nicotiana bigelovii var. bigelovii, who found that some habituated callus lines exhibit the capacity to regenerate normal shoots for a period of several months.

Healthy elongated shoots were excised and placed on half-strength MS basal medium supplemented with different concentrations $\left(0.1,0.5,1.0,1.5\right.$ and $\left.2.0 \mathrm{mg} \mathrm{L}^{-1}\right)$ of IBA and NAA for the induction of roots. The effect of auxins on both root induction and root length was examined after 4 weeks of culture, and IBA was found to be the most effective for root induction (Table 3). High frequency rooting $(90 \%)$ and a mean root number of $4.8 \pm 0.3$ with a length of $1.6 \pm 0.03 \mathrm{~cm}$ were obtained on the medium containing 0.5 and $1.0 \mathrm{mg} \mathrm{L}^{-1} \mathrm{IBA}$, respectively. (Figure $2 \mathrm{H})$. Increasing the IBA concentration from 1.0 to $2.0 \mathrm{mg}$
$\mathrm{L}^{-1}$ reduced the number of roots per shoot. Increasing the concentration of NAA was also unfavorable for adventitious root formation. Additionally, $65 \%$ rooting and a mean root number of $3.3 \pm 0.4$ with a length of $0.6 \pm 0.04 \mathrm{~cm}$ were obtained on half-strength MS medium without any PGRs. Similar to our observation, Nathar and Yatoo (2014) found a lower salt concentration to be effective for in vitro root induction. High efficiency of IBA for in vitro root induction compared to other auxins has been earlier reported (Bouhouche and Ksiksi 2007). However, root induction with a medium containing a higher concentration $(1.0 \mathrm{mg}$ $\mathrm{L}^{-1}$ ) of IBA was accompanied by a profuse development of calli, which inhibited further development of roots. This result is consistent with similar findings in root induction of Thymus spp. where the percentage of rooting was reduced at a higher concentration of IBA (Olszowska and Furmanowa 1992). Media containing NAA generally produced short thick roots, some of which were callogenic, whilst media including IBA as well as medium without any PGRs (control) produced long thin roots.

Plantlets with more than four roots longer than $10 \mathrm{~mm}$ were transferred to ex vitro conditions and acclimatized. After hardening in a soil mixture of peat moss and perlite (1:1) for three weeks, regenerated $T$. persicus plantlet survival was over $80 \%$, but the rate then decreased, as some plants died in the 4-5 weeks following their transfer to soil. It was observed that $T$. persicus in vitro grown plants require a very gradual acclimatization to the external environment. Seventy-five percent of the plants transferred to pots survived and resumed growth (Figure 2I). No morphological alterations were observed among regenerated plants grown in the greenhouse. Similar observations have been reported in Salvia (Tawfik and Mohamed 2007).

Table 3. Effect of auxin type and concentration in half-strength MS medium on root formation from regenerated shoots of Thymus persicus

\begin{tabular}{|c|c|c|c|c|c|}
\hline PGR & $\begin{array}{c}\text { Concentration } \\
\left(\mathrm{mg} \mathrm{L}^{-1}\right)\end{array}$ & $\begin{array}{c}\text { Root formation } \\
(\%)\end{array}$ & $\begin{array}{c}\text { Mean number of roots } \\
\text { (no. } \pm \mathrm{SE} \text { ) }\end{array}$ & $\begin{array}{l}\text { Mean root length } \\
(\mathrm{cm} \pm \mathrm{SE})\end{array}$ & Root morphology \\
\hline \multirow{3}{*}{ IBA } & 0.1 & $60^{\mathrm{d}}$ & $2.7 \pm 0.1^{\mathrm{ab}}$ & $0.7 \pm 0.07^{\mathrm{ab}}$ & Thin, long \\
\hline & 1.0 & $88^{\mathrm{ab}}$ & $4.8 \pm 0.3^{\mathrm{a}}$ & $1.6 \pm 0.03^{\mathrm{a}}$ & Fragile, long \\
\hline & 1.5 & $67^{\mathrm{c}}$ & $1.7 \pm 0.2^{\mathrm{ab}}$ & $0.9 \pm 0.04^{\mathrm{ab}}$ & Fragile, long \\
\hline \multirow{4}{*}{ NAA } & 0.5 & $47^{\mathrm{ef}}$ & $3.8 \pm 0.9^{\mathrm{a}}$ & $0.5 \pm 0.09^{\mathrm{ab}}$ & Thick, short \\
\hline & 1.0 & $50^{\mathrm{e}}$ & $2.6 \pm 0.6^{\mathrm{ab}}$ & $0.4 \pm 0.04^{\mathrm{ab}}$ & Thick, short, callus at base \\
\hline & 1.5 & $40^{\mathrm{f}}$ & $0.5 \pm 0.4^{\mathrm{b}}$ & $0.3 \pm 0.01^{\mathrm{b}}$ & Thick, short, callus at base \\
\hline & 2.0 & $25^{\mathrm{g}}$ & $0.2 \pm 0.1^{b}$ & $0.2 \pm 0.02^{\mathrm{b}}$ & Thick, short, callus at base \\
\hline
\end{tabular}

Each value represents Mean \pm SE. Mean values followed by the same letter are not significantly different at $\mathrm{P}<0.05$ (Least Significant Difference Test). Results recorded after 3 weeks of culture. 


\section{CONCLUSION}

In conclusion, the effectiveness of callus induction and plant regeneration depends on the type of growth regulators used and explant source. The results of this work showed that in vitro-cultured $T$. persicus explants respond differently according to the growth regulators added to the culture medium. Maximum callus induction $(100 \%)$ was obtained on internode segments cultured on MS medium supplemented with $2 \mathrm{mg} \mathrm{L}^{-1}$ of NAA and $0.5 \mathrm{mg} \mathrm{L}^{-1}$ of $\mathrm{KN}$. A combination of BAP and NAA as MS medium supplements proved to be an effective PGR combination, with significantly higher shoot induction and multiplication frequencies. The highest number of shoots per explant was obtained on MS medium supplemented with $2 \mathrm{mg} \mathrm{L}^{-1} \mathrm{BAP}$ and $1.0 \mathrm{mg} \mathrm{L}^{-1} \mathrm{NAA}$. Auxin type and concentration significantly influenced the formation of roots, IBA being the most effective. High frequency rooting $(88 \%)$ and a mean root number of 4.8 \pm 0.3 with a length of $1.6 \pm 0.03 \mathrm{~cm}$ were achieved on the

\section{REFERENCES}

Aicha $\mathrm{N}$ and Abdelmalek E (2014) In vitro regeneration and clonal multiplication of Thymus bleicherianus Pomel, a rare and threatened medicinal and aromatic in Morocco. Medicinal \& Aromatic Plants 3: 1 .

Bakhtiar Z, Mirjalili MH, Sonboli A, Moridi Farimani M and Ayyari M (2014) In vitro propagation, genetic and phytochemical assessment of Thymus persicus - a medicinally important source of pentacyclic triterpenoids. Biologia 69: 594-603.

Bennici A and Bruschi P (1999) Stability of habituation in Nicotiana bigelovii var. bigelovii shoots regenerated from habituated callus. Plant Science 143: 195-199.

Bouhouche $\mathrm{N}$ and Ksiksi T (2007) An efficient in vitro plant regeneration system for the medicinal plant Teucrium stocksianum Boiss. Plant Biotechnology Reports 1: 179-184.

Brown DCW and Thorpe TA (1995) Crop improvement through tissue culture. World Journal of Microbial \& Biotechnology 11: 409-415.

Chudzik M, Korzonek-Szlacheta I and Krol W (2015) Triterpenes as potentially cytotoxic compounds. Molecules 20: 1610-1625

Coelho N, Goncalves S, Elena M, Benito G and Romano A (2012) Establishment of an in vitro propagation protocol for Thymus lotocephalus, a rare aromatic species of the Algarve (Portugal). Plant Growth Regulation 66: 69-74.

Fay M (1992) Conservation of rare and endangered plants using in vitro methods. In Vitro Cellular \& Developmental Biology - Plant 28: $1-4$.

George EF (1993) Plant Propagation by Tissue Culture. Eastern Press, Eversley, 574p.

Hawkes JG, Maxted N and Ford-Lloyed BV (2000) The ex situ medium containing $0.5 \mathrm{mg} \mathrm{L}^{-1}$ IBA.

The method described for the first time in the present study provides an efficient reproducible protocol for in vitro micropropagation of $T$. persicus as a potent natural source of antitumor pentacyclic triterpenes. This protocol can also be used for the mass production of $T$. persicus plants, thus contributing to the germplasm conservation of this endangered and valuable medicinal species in the wild. The application of the protocol will facilitate research into the enhanced production of antitumor compounds through different biotechnological strategies, such as plant cell, tissue and organ cultures, and large-scale cultivation in bioreactors.

\section{ACKNOWLEDGEMENTS}

The authors gratefully acknowledge the Shahid Beheshti University Research Council for financial support of this project. This work was part of Ziba Bakhtiar master's thesis.

conservation of plant genetic resources. Kluwer Academic Publishers, Dordrecht, 249p.

Jalas J (1982) Thymus. In Rechinger KH (ed) Flora Iranica. Springer, New York, p. 536-538.

Jalili A and Jamzad Z (1999) Red data book of Iran: A preliminary survey of endemic, rare \& endangered plant species in Iran. Research Institute of Forest and Rangelands Publication, Tehran, 748p.

Kour B, Azhar M, Kaul S and Dhar MK (2014) In vitro regeneration and mass multiplication of Prunella vulgaris L. National Academy Science Letters 37: 81-86.

Lawrence BM and Tucker AO (2002) The genus Thymus as a source of commercial products. In Stahl-Biskup E and Sáez F (eds) Thyme, the genus Thymus. Taylor and Francis, London, p. 252-262.

Lee PL and Chen JT (2014) Plant regeneration via callus culture and subsequent in vitro flowering of Dendrobium houshanense. Acta Physiologia Plantarum 36: 2619-2625.

Liu M, Yang S, Jin L, Hu D, Wu Z and Yang S (2012) Chemical constituents of the ethyl acetate extract of Belamcanda chinensis (L.) DC roots and their antitumor activities. Molecules 17: 6156-6169.

Machado MP, Silva ALL, Biasi LA, Deschamps C, B Filho JC and Zanette F (2014) Influence of calcium content of tissue on hyperhydricity and shoot-tip necrosis of in vitro regenerated shoots of Lavandula angustifolia Mill. Brazilian Archives of Biology and Technology 57: 636-643.

Morales R (2002) The history, botany and taxonomy of the genus Thymus. In Stahl-Biskup E and Sáez F (eds) Thyme, the genus Thymus. Taylor and Francis, London, p. 1-43.

Mozaffarian V (1996) A Dictionary of Iranian plant names. Farhang Moaser, Tehran, p. 190. 


\section{Z Bakhtiar et al.}

Murashige T and Skoog F (1962) A revised medium for rapid growth and bio assays with tobacco tissue cultures. Physiologia Plantarum 15: 473-497.

Nathar VN and Yatoo GM (2014) Micropropagation of an antidiabetic medicinal plant, Artemisia pallens. Turkish Journal of Botany 38: 491-498.

Nordine A, Tlemcani CR and El-Meskaoui A(2014) Regeneration of plants through somatic embryogenesis in Thymus hyemalis Lange, a potential medicinal and aromatic plant. In Vitro Cellular \& Developmental Biology - Plant 50: 19-25.

Olszowska O and Furmanowa M (1992) Micropropagation of thyme (Thymus vulgaris L.) from stem fragments with nodes. Herba Polonica 33: 137-144.

Ozudogru EA, Kaya E, Kirdok E and Issever-ozturk S (2011) In vitro propagation from young and mature explants of thyme (Thymus vulgaris and $T$. longicaulis) resulting in genetically stable shoots. In Vitro Cellular \& Developmental Biology - Plant 47: 309-320.

Poovaiah CR, Weller SC and Jenks MA (2006) In vitro adventitious shoot regeneration of native spearmint using internodal explants.
Hortscience 41: 414-417.

Reddy P, Kandisa RV, Varsha PV and Satyam S (2014) Review on Thymus vulgaris traditional uses and pharmacological properties. Medicinal \& Aromatic Plants 3: 164-166.

Sidhu Y (2010) In vitro micropropagation of medicinal plants by tissue culture. The Plymouth Student Scientist 4: 432-449.

Stahl-Biskup E (2002) Thyme as a herbal drug-pharmacopoeias and other product characteristics. In Stahl-Biskup E and Sáez F (eds) Thyme, the genus Thymus. Taylor and Francis, London, p. 293-316.

Tawfik AA and Mohamed MF (2007) Regeneration of salvia (Salvia officinalis L.) via induction of meristematic callus. In Vitro Cellular \& Developmental Biology - Plant 43: 21-27.

Ueno K, Fukunaga Y and Arisumi K (1996) Genetic transformation of Rhododendron by Agrobacterium tumefaciens. Plant Cell Reports 16: $38-41$.

Zorat Cordeiro S, Kato Simas N, Borges Henriques A and Sato A (2014) Micropropagation and callogenesis in Mandevilla guanabarica (Apocynaceae), an endemic plant from Brazil. Crop Breeding and Applied Biotechnology 14: 108-115. 